\title{
Benzo $[a]$ pyrene in urban environments of eastern Moscow: pollution levels and critical loads
}

\author{
Nikolay S. Kasimov, Natalia E. Kosheleva, Elena M. Nikiforova, and Dmitry V. Vlasov \\ Department of Landscape Geochemistry and Soil Geography, Faculty of Geography, Lomonosov Moscow State University, \\ Moscow 119991, Russia \\ Correspondence to: Dmitry V. Vlasov (vlasov.msu@gmail.com)
}

Received: 20 July 2016 - Discussion started: 11 October 2016

Revised: 20 January 2017 - Accepted: 31 January 2017 - Published: 14 February 2017

\begin{abstract}
Polycyclic aromatic hydrocarbons (PAHs), particularly benzo $[a]$ pyrene $(\mathrm{BaP})$, are toxic compounds emitted from various anthropogenic sources. Understanding the $\mathrm{BaP}$ concentrations, dynamics and decomposition in soil is required to assess the critical loads of $\mathrm{BaP}$ in urban environments. This study is the first attempt to evaluate all major input and output components of benzo[a]pyrene (BaP) balance and to calculate the permissible load on the urban environment in different land-use zones in the Eastern district of Moscow. BaP contamination of the snow cover in the Eastern district of Moscow was related to daily $\mathrm{BaP}$ fallout from the atmosphere. In 2010, the mean content of the pollutant in the snow dust was $1942 \mathrm{ng} \mathrm{g}^{-1}$, whereas the average intensity of its fallout was $7.13 \mathrm{ng} \mathrm{m}^{-2}$ per day. Across the territory, BaP winter fallout intensities varied from 0.3 to $1100 \mathrm{ng} \mathrm{m}^{-2}$ per day. The average $\mathrm{BaP}$ content in the surface $(0-10 \mathrm{~cm})$ soil horizons was $409 \mathrm{ng} \mathrm{g}^{-1}$, which is 83 times higher than the local background value and 20 times higher than the maximum permissible concentration (MPC) accepted in Russia. The variations in soil and snow $\mathrm{BaP}$ concentrations among different land-use zones were examined. A significant contribution of $\mathrm{BaP}$ from the atmosphere to urban soils was identified. Based on the measurements of $\mathrm{BaP}$ atmospheric fallout and $\mathrm{BaP}$ reserves in the soils, the critical loads of $\mathrm{BaP}$ for the land-use zones in the Eastern district were calculated for different values of degradation intensity and different exposure times. It was established that at an annual degradation intensity of $1-10 \%$, ecologically safe BaP levels in the soils of all land-use zones, excluding the agricultural zone, will only be reached after many decades or centuries.
\end{abstract}

\section{Introduction}

The early 21 st century is characterized by a significant exacerbation of environmental problems, especially in large industrial and urban centres. According to demographic projections, by 2050 about $66 \%$ of the 9 billion people on Earth will be living in cities (UN DESA, 2015), which will lead to an increase in the anthropogenic impact on the environment and its further contamination.

Toxic substances, like polycyclic aromatic hydrocarbons (PAHs) and their most dangerous member, benzo $[a]$ pyrene $(\mathrm{BaP})$ with its carcinogenic and mutagenic properties, are of significant importance in environmental studies (Haglund et al., 1987; Gennadiev and Pikovskii, 1996; Garban et al., 2002; Chung et al., 2007; Jacob, 2008; Pergal et al., 2015). This gives a special relevance to research focused on the long-term dynamics of $\mathrm{BaP}$ content in the urban environment related to the intensity of $\mathrm{BaP}$ emissions from anthropogenic sources and its accumulation in and destruction of soils.

$\mathrm{BaP}$ is released from industrial, heating, vehicle and domestic waste. It is also a byproduct of organic waste and fuel combustion (Larsen and Baker, 2003; Pergal et al., 2015). $\mathrm{BaP}$ is added to the urban environment from polluted air with dust, precipitation and aerosols and accumulates in the surface layers of soils (Wania and MacKay, 1996; Trapido, 1999; Fernández et al., 2000; Nam et al., 2009). In the United Kingdom, over $90 \%$ of all PAH reserves in the environment are limited to the surface layer of soil (Wild and Jones, 1995). PAH concentration in the air is generally significantly higher in winter than in summer because of greater fuel combustion (Ollivon et al., 2002; Gaga et al., 2009; Birgül et al., 2011).

In many major cities of the world, $\mathrm{BaP}$ concentrations in the environment are 10 to 100 times higher than the regional 
values (Trapido, 1999; Ma et al., 2005). Long-term (19902006) monitoring of BaP concentrations in the Eastern Administrative District (EAD), one of the most polluted parts of Moscow, demonstrates a steady increase in pollution and related deterioration of soil functioning (Kosheleva and Nikiforova, 2011).

The rate of $\mathrm{BaP}$ accumulation in soil depends on the balance between its fallout from the atmosphere and the intensity of removal and decomposition. BaP addition to urban soil is almost entirely derived from anthropogenic sources, whereas $\mathrm{BaP}$ removal through volatilization, degradation and leaching depends on landscape, geochemical and bioclimatic factors (Morillo, 2008; Kosheleva and Nikiforova, 2011). $\mathrm{BaP}$ input is measured by the rates of its deposition with road and industrial dust (Yu et al., 2014). In cities with cold climates, the $\mathrm{BaP}$ deposition from the atmosphere can be determined by examining $\mathrm{BaP}$ reserves in the snow cover (Haglund et al., 1987; Kasimov, 1995; Sharma and McBean, 2001). However, particulate matter and the water-soluble fraction of snow are rarely analyzed for $\mathrm{BaP}$ contents, so the contribution of these fractions to the formation of $\mathrm{BaP}$ anomalies in the urban environment has so far been poorly studied.

Among the individual PAHs, BaP is the least soluble in natural fresh waters and has a limited ability to be leached from the soils. Therefore, the losses of $\mathrm{BaP}$ from the soils are mostly determined by its destruction, which is enhanced by ultraviolet radiation (Gennadiev and Pikovskii, 1996). The rates of $\mathrm{PAH}$ and $\mathrm{BaP}$ molecule transformation are also heavily dependent on soil properties, such as $\mathrm{pH}$, soil organic matter (SOM) content, particle aggregation, texture, redox conditions and heat and water fluxes and regimes. PAH and $\mathrm{BaP}$ biodegradation is affected by the molecular structure of specific compounds (Wild and Jones, 1995; Doelman, 1995; Kleeman et al., 2000; Johnsen and Karlson, 2007; Jiang et al., 2009; Birke et al., 2011; Kosheleva and Nikiforova, 2011; Kasimov et al., 2014).

The determination of $\mathrm{BaP}$ input and losses makes it possible to evaluate the resilience of urban soils to organic pollutants and to assess the possibility of their self-purification. The concept of critical loads on the urban environment provides a methodological framework for this kind of research. The critical load of a pollutant is defined as the maximal input to an ecosystem that does not lead to irreversible changes in its biochemical structure, biodiversity or productivity over a long period of time (Vries et al., 1997; Baskhin et al., 2004). So, the aim of the present study is to analyze the fate of $\mathrm{BaP}$ in the urban environment of the EAD of Moscow using the concept of critical loads. The particular tasks are as follows:

- to identify the intensity of atmospheric BaP addition to the snow cover in the winter period on the basis of dust deposition rates and the $\mathrm{BaP}$ contents in the solid fraction of snow;
- to determine $\mathrm{BaP}$ concentrations and to reveal the specific features of $\mathrm{BaP}$ spatial distribution in the soil cover of the EAD, including the localization and size of anthropogenic anomalies;

- to assess the ecological risk of $\mathrm{BaP}$ pollution on the basis of sanitary and hygienic standards for $\mathrm{BaP}$ concentration in soils, as accepted in Russia by legislation;

- and to calculate BaP critical loads on urban soils with respect to $\mathrm{BaP}$ degradation rates and exposure periods.

\section{Materials and methods}

\subsection{Study area}

The work was conducted in the territory of Moscow, one of the largest cities in the world with a population of about 12 million. The city of Moscow is divided into 12 administrative districts. The study area is located in the eastern part of Moscow, which is considered to be one of the most polluted in the city because of its large industrial sector and concentration of large processing enterprises. The study area belongs to the southern taiga landscapes of the Meschera lowland, which is a flat outwash plain with mean altitudes of about $150 \mathrm{~m}$ (Fig. 1). The land surface is dominated by urban structures. Urbic Technosols dominate in the soil cover; their morphological, physical and chemical properties differ greatly from those of the background Retisols developing under coniferous-deciduous forests on loamy deposits (Kosheleva and Nikiforova, 2011). Anthropogenically modified and artificial soils are also represented by Eutric Retisols, Transportic Technosols, Ekranic Technosols (sealed by asphalt) and by several other soil types developed on man-made sediments and the cultural layer (Prokof'eva et al., 2014).

Traffic releases more than $90 \%$ of pollutants in the aerosol and gas phase, including PAHs, into the air and thus defines the ecological situation in the district (Kasimov et al., 2014). Car exhaust emissions from large highways cause a significant adverse effect on urban soils (Fig. 1). A few large industrial zones with chemical and petrochemical plants and two thermal power plants are also sources of $\mathrm{BaP}$ pollution.

\subsection{Sampling}

The snow cover in the EAD was surveyed in early March when the snow depth was maximal, while the soil sampling was carried out in June 2010 using the methods recommended in Revich et al. (1982) and Kasimov (1995). Landuse zoning was accomplished and traffic, industrial, residential, recreational and agricultural zones were distinguished (Nikiforova et al., 2014). Overall, 50 snow and 50 topsoil (0$10 \mathrm{~cm}$ ) samples were collected at the same locations at a regular grid with $800 \mathrm{~m}$ intervals. Composite snow samples were 


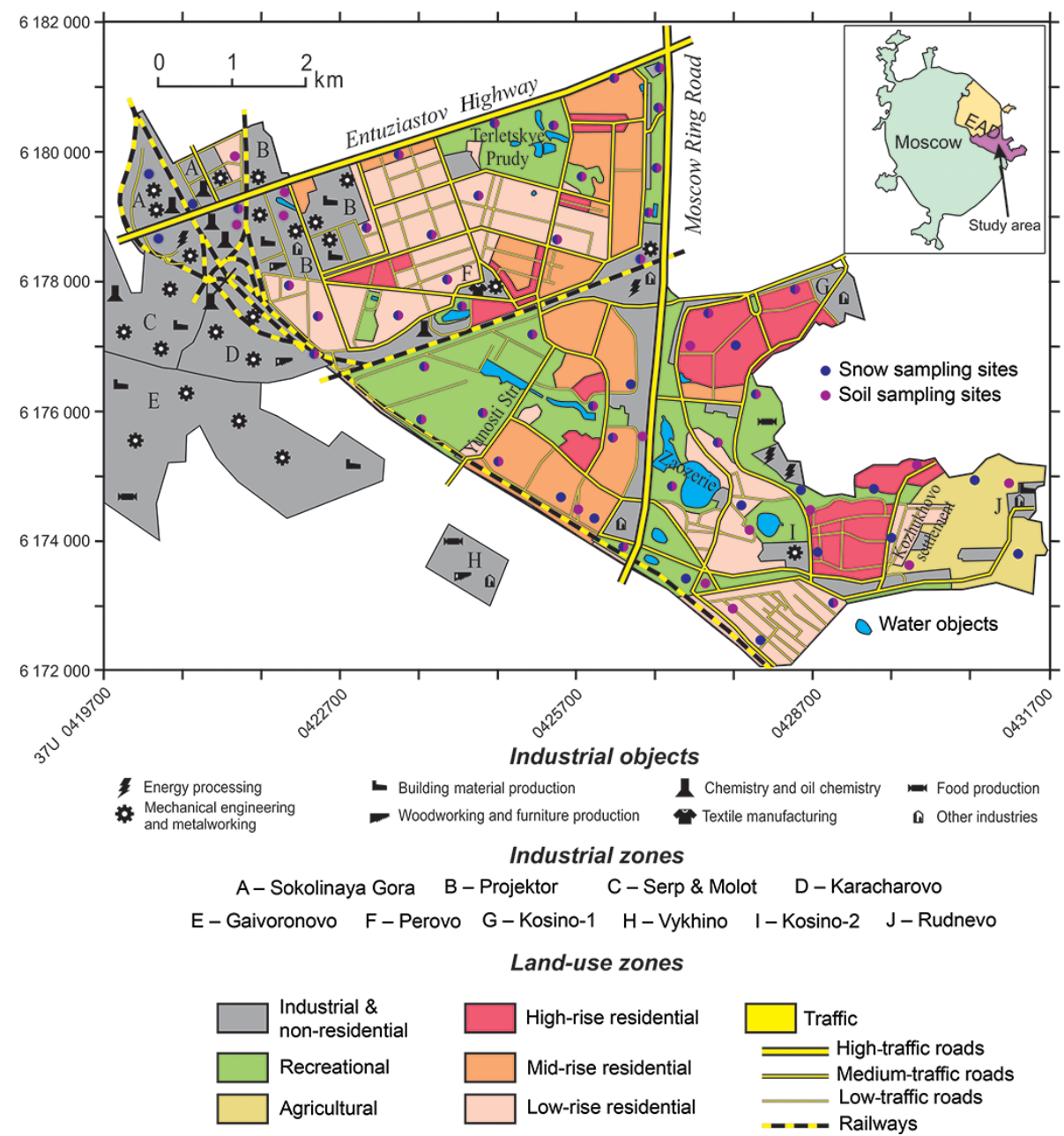

Figure 1. Land-use zoning of the study area with main sources of BaP and locations of the sampling points; the UTM coordinate system.

formed by mixing 10 replicate samples taken with a plastic tube $5 \mathrm{~cm}$ in diameter; the composite soil samples were compiled from 3-4 individual samples. Due to a prevailing western atmospheric transfer, background (reference) snow samples were collected $50 \mathrm{~km}$ west of Moscow, near the city of Zvenigorod. The background area for urban soils was located in the Meschera lowland, 40-50 km east of Moscow, since the natural soils in that area (Retisols) were formed on the same parent materials (sandy clays and light clay loams) as the urban soils.

\subsection{Laboratory technique and analysis}

The solid fraction (particulate matter) was separated from snow samples using a membrane filter with a pore diameter of $0.45 \mu \mathrm{m}$. The $\mathrm{BaP}$ contents in the snow solid fraction and in the bulk soil samples were measured via lowtemperature spectrofluorimetry under the Shpolsky effect using the "Fluorat-02-Panorama" (Lumex Instruments, Mission, BC, Canada), which was supplemented by an "LM-3" monochromator and a "CRYO-1" cryogenic attachment with a precision of $\pm 25 \%$ (Alekseeva and Teplitskaya, 1981). The cold extraction of $\mathrm{BaP}$ is carried out with $n$-hexane, and its concentration is determined by gas chromatography-mass spectrometry (GC-MS) with a precision of $15-20 \%$ (Gennadiev and Pikovskii, 1996).

The geochemical data treatment included the calculation of the enrichment factor (EF), which compares the abundances of $\mathrm{BaP}$ in urban soils to the reference value. For assessing the risk of contamination, the ecological risk index (PI) was estimated on the basis of the maximum permissible concentration (MPC), which is a general BaP sanitary level equal to $20 \mathrm{ng} \mathrm{g}^{-1}$ (GN.2.1.7.2041-06). The intensity of BaP atmospheric fallout, $\mathrm{ng} \mathrm{m}^{-2}$ per day, is calculated as follows: $D=P_{n} \times C$, where $P_{n}$ is the daily dust deposition on the urban territory $\left(\mathrm{g} \mathrm{m}^{-2}\right)$ and $C$ is the $\mathrm{BaP}$ concentration in the solid fraction of snow $\left(\mathrm{ng} \mathrm{g}^{-1}\right)$. In $P_{n}=m /(n \cdot l \cdot s), m$ is the mass of solid matter in a snow sample, ng; $n$ is the number of tubes with snow collected in sampling points; $l$ is the number of days with snow cover; and $s$ is the cross-sectional area of 
Table 1. $\mathrm{BaP}$ contents in the solid fraction of snow and $\mathrm{BaP}$ fallout intensities in the winter period for the background territory and the land-use zones in the EAD of Moscow (2010).

\begin{tabular}{|c|c|c|c|c|c|c|c|c|}
\hline \multirow[t]{3}{*}{ Indices } & \multirow[t]{3}{*}{ B (10) } & \multicolumn{7}{|c|}{ Land-use zones* (number of samples) } \\
\hline & & \multirow[t]{2}{*}{$\mathrm{T}(13)$} & \multirow[t]{2}{*}{$\mathrm{I}(5)$} & \multicolumn{3}{|c|}{ residential areas } & \multirow[t]{2}{*}{ A (3) } & \multirow[t]{2}{*}{$\mathrm{R}(6)$} \\
\hline & & & & $\mathrm{L}(5)$ & M (13) & $\mathrm{H}(5)$ & & \\
\hline \multicolumn{9}{|c|}{$\mathrm{BaP}$ content in the solid fraction of snow } \\
\hline Average, $\mathrm{ng} \mathrm{g}^{-1}$ & 169 & 3605 & 5732 & 604 & 1225 & 224 & 197 & 154 \\
\hline Min-max & $69.4-489$ & $26.7-22530$ & $275-22040$ & $232-1466$ & $13.2-7278$ & $14,5-466$ & $149-238$ & $14.2-379$ \\
\hline$C_{\mathrm{V}}, \%$ & 106 & 201 & 163 & 84,8 & 178 & 77.8 & 22.9 & 90.2 \\
\hline $\mathrm{EF}$ & 1.0 & 21.3 & 33.9 & 3.57 & 7.25 & 1.32 & 1.16 & 0.91 \\
\hline \multicolumn{9}{|c|}{$\mathrm{BaP}$ fallout intensity with the solid fraction of snow onto the soil surface } \\
\hline Average, $\mathrm{ng} \mathrm{m}^{-2}$ per day & 2.0 & 163 & 189 & 18.7 & 43.2 & 7.2 & 3.4 & 2.4 \\
\hline Min-max & $1.2-5.4$ & $1.8-1150$ & $8.9-495$ & $0.3-21.4$ & $0.3-283$ & $0.3-21.4$ & $2.4-4.2$ & $0.3-4.8$ \\
\hline$C_{\mathrm{V}}, \%$ & 92.1 & 193 & 125 & 102 & 190 & 116 & 27.0 & 80.2 \\
\hline $\mathrm{LF}$ & 1.0 & 80.7 & 93.4 & 9.24 & 21.4 & 3.56 & 1.66 & 1.18 \\
\hline \multicolumn{9}{|c|}{$\mathrm{BaP}$ content in the background and urban soils } \\
\hline Average, ng g $^{-1}$ & 4.93 & 566 & 1563 & 84.3 & 283 & 34.6 & 4.7 & 164 \\
\hline Min-max & $0-15$ & $1.4-3278$ & 299-3611 & $1.3-299$ & $7.0-1273$ & $0-67.0$ & $0-14.0$ & 0-798 \\
\hline$C_{\mathrm{v}}, \%$ & 92.7 & 153 & 83.8 & 147 & 131 & 85.6 & 171 & 194 \\
\hline $\mathrm{EF}$ & 1.0 & 115 & 317 & 17.1 & 57.4 & 7.02 & 0.95 & 33.3 \\
\hline
\end{tabular}

* Here and in Tables 2 and 3 and Fig. 2, land-use zones are denoted as follows: B, background; T, traffic; I, industrial; H, M and L, residential areas with high-, mid- and

low-rise buildings respectively; A, agricultural; and R, recreational.

the tube in $\mathrm{m}^{2}$. The excess of $\mathrm{BaP}$ atmospheric fallout over the background level is defined as $\mathrm{LF}=D / D_{\mathrm{b}}$, where $D$ and $D_{\mathrm{b}}$ refer to the $\mathrm{BaP}$ fallout intensities on the urban and background areas respectively. The balance calculations were performed using averaged data for land-use zones, so the accuracy of the balance components was 2-3 times higher than those in the single samples. This provided sufficient reliability of the BaP critical load values.

\section{Results and discussion}

\subsection{BaP concentrations in snow and its deposition from the atmosphere in background and urban environments}

$\mathrm{BaP}$ is commonly added to soil cover through atmospheric precipitation, falling either in liquid or solid phases. Since the velocity of snowfall is slower and snowflakes have larger surfaces compared to raindrops, they become rich in $\mathrm{BaP}$ faster (Vasilenko et al., 1985).

In the background area near Zvenigorod, the snow is weakly acidic ( $\mathrm{pH}$ 5.8). The average $\mathrm{BaP}$ content in the dust fraction of snow is $169 \mathrm{ng} \mathrm{g}^{-1}$ (Table 1), which denotes low atmospheric addition of $\mathrm{BaP}$ to the background soils. $\mathrm{BaP}$ distribution in the snow cover is characterized by high spatial variability with a variation coefficient $\left(C_{\mathrm{v}}\right)$ of $106 \%$. BaP fallout intensity is estimated to be approximately $2 \mathrm{ng} \mathrm{m}^{-2}$ per day, which is close to the values of $0.1-2.2 \mathrm{ng} \mathrm{m}^{-2}$ per day measured by passive sampling and reported for the unpolluted area in the Serpukhovsky District of the Moscow region by Chernyansky et al. (2007).

The estimations performed by Gabov et al. (2008) for the undisturbed territories of the East European Plain in the taiga zone showed that the annual average rate of $\mathrm{BaP}$ deposition with dust and snowfall to the soil surface is $30-40 \mathrm{ng} \mathrm{m}^{-2}$. These elevated fallout values were explained by a large atmospheric concentration of $\mathrm{BaP}$ due to high anthropogenic emissions on a regional level.

In this study, snow water in urban areas had a higher $\mathrm{pH}$ in relation to the background level. This is especially apparent in industrial zones ( $\mathrm{pH}$ 7.6) and in residential areas with high-rise buildings outside the Moscow Ring Road $(\mathrm{pH}$ 6.4). The solid fraction of snow in the EAD was enriched with $\mathrm{BaP}$ : its average content was $1942 \mathrm{ng} \mathrm{g}^{-1}$, which was 11.5 times higher than the background level. BaP contents in the snow differed dramatically across the land-use zones (Table 1). They can be arranged according to their corresponding enrichment factor (EF) values in the following order: industrial (34), traffic (21), mid-rise residential blocks (7), lowrise quarters (4), high-rise blocks (1.3), agricultural (1.2) and recreational (0.9). The $\mathrm{BaP}$ content in the solid fraction of snow in particular land-use zones varied within a wide range: $C_{\mathrm{v}}$ exceeded $100 \%$ in five out of seven zones (Table 1). 
BaP delivery from the atmosphere is defined not only by its content in solid particles of snow, but also by its fallout intensity. In the EAD, the $\mathrm{BaP}$ fallout with the snow dust during the winter period was quite significant, and it averaged $75.6 \mathrm{ng} \mathrm{m}^{-2}$ per day, ranging from 189 in the industrial zone to 2.4 in the recreational zone (Table 1).

$\mathrm{BaP}$ fallout, measured as the loading factor (LF), in the two most polluted zones was much higher than in the background territories ( $\mathrm{LF}=93-80)$; however, the difference between the recreational zone and the reference sites was insignificant $(\mathrm{LF}=1.2)$. These data on the intensity of $\mathrm{BaP}$ fallout with snow dust were consistent with the results reported for the city of Bratsk, Siberia. In the industrial zone of Bratsk, where a large aluminum plant and a pulp and paper factory are located, the $\mathrm{BaP}$ load rose to $1000 \mathrm{ng} \mathrm{m}^{-2}$ per day, while in the residential area of the central district it was 100-200 $\mathrm{ng} \mathrm{m}^{-2}$ per day (Kasimov, 1995).

The mean anthropogenic $\mathrm{BaP}$ addition to soil cover in Moscow's EAD (75.6 $\mathrm{ng} \mathrm{m}^{-2}$ per day) is comparable to fallout levels in other urban territories of the world with industrial and transport emissions of BaP. For example, in Bursa, Turkey, the daily BaP deposition was $100-1000 \mathrm{ng} \mathrm{m}^{-2}$ (Esen et al., 2008; Birgül et al., 2011); in Ankara it was $65 \mathrm{ng} \mathrm{m}^{-2}$ in spring and winter and $10 \mathrm{ng} \mathrm{m}^{-2}$ in summer and autumn (Gaga et al., 2009). In Jersey City, NJ, USA, the daily $\mathrm{BaP}$ addition with precipitation was $25 \mathrm{ng} \mathrm{m}^{-2}$, and dry deposition accounted for $83 \mathrm{ng} \mathrm{m}^{-2}$ (Gigliotti et al., 2005). In Nahant, MA, USA, BaP fallout increased to $71 \mathrm{ng} \mathrm{m}^{-2}$ day $^{-1}$ (Golomb et al., 1997), while in Kuopio, Finland, the fallout ranged from 40 to $250 \mathrm{ng} \mathrm{m}^{-2}$ day $^{-1}$ (Hautala et al., 1995).

\subsection{BaP in background and urban soils}

The surface horizons of the background soils, which are represented by Retisols, were acidic ( $\mathrm{pH}$ 5.5) with low BaP concentrations that were 34 times lower than the mean BaP value in the solid fraction of snow (Table 1). Still, like dust in the snow cover, the natural soils showed typically high variability of BaP contents $\left(C_{\mathrm{v}}=92.7 \%\right)$. For example, undisturbed Norwegian soils had the same level $\left(5 \mathrm{ng} \mathrm{g}^{-1}\right)$ of BaP content, but the world background soils were characterized by higher $\mathrm{BaP}$ values of - $22 \mathrm{ng} \mathrm{g}^{-1}$ (Nam et al., 2009).

Urban soils were weakly alkaline, ranging in the reaction from basic ( $\mathrm{pH} 8.1$ in the industrial zone) to weakly acidic ( $\mathrm{pH} 6.5$ in the recreational zone). Based on our data, the average $\mathrm{BaP}$ concentration was $409 \mathrm{ng} \mathrm{g}^{-1}$, which was 43 times higher than the background level. The BaP content varied greatly across land-use zones (Table 1), reaching a maximum in the industrial zone and along highways, where the surface horizons represent well-defined anthropogenic geochemical barriers (Kosheleva et al., 2015). According to the BaP enrichment of the surface layers, the land-use zones can be arranged in the following order by EF: industrial (241), large highways (115), mid-rise residential (72), recreational (66), low-rise quarters (19), high-rise blocks (11) and agricultural
(0.9). BaP concentrations in the urban soils vary greatly: the variation coefficients $C_{\mathrm{V}}$ exceed $130 \%$ in five out of seven zones.

In the majority of land-use zones, the solid fraction of snow had higher (4-7 times) $\mathrm{BaP}$ concentrations than the surface soil layers. This situation is typical for cases where relatively high $\mathrm{BaP}$ concentration is observed for the airborne particles (Amagai et al., 1999). In the agricultural zone, the relative enrichment of snow dust with $\mathrm{BaP}$ increased up to 42 times with respect to soil material. The difference between the BaP content in the snow and in the soils can be attributed to two factors. First, nearby sources, such as the Kozhukhovo settlement with homes individually heated by furnaces and the Rudnevo industrial zone with a waste incineration plant, probably released a considerable amount of BaP. Second, the cultivated soils in this zone had higher BaP decomposition rates compared to the soils in other zones due to favourable moisture and air regimes (Nikiforova and Alekseeva, 2005). The ratio between the average $\mathrm{BaP}$ concentrations in snow and in the surface soil horizons indicated a significant BaP addition from the atmosphere and its progressive accumulation in the soils, especially in the industrial and traffic zones.

In order to evaluate the ecological risk associated with $\mathrm{BaP}$ soil pollution, the average concentrations of $\mathrm{BaP}$ in the district's land-use zones were compared with the sanitary standards (MPC) accepted in Russia. The highest risk index (PI) was revealed in the industrial zone $(\mathrm{PI}=78)$, followed by the traffic zone (28) and residential areas with mid-rise buildings (14). The lowest level of risk was observed in the residential high-rise (1.7) and agricultural (0.2) zones outside the Moscow Ring Road. The average BaP content in the urban soils exceeded the norm by 20 times, indicating that the soils were in an extremely dangerous ecological condition with regards to $\mathrm{BaP}$ pollution. Territories where the $\mathrm{BaP}$ content was 30 or more times higher than the MPC make up $20 \%$ of the district's area, whereas $35 \%$ of the area was occupied by soils with $\mathrm{BaP}$ concentrations 10-30 times higher than the MPC. The rest of the EAD territory was occupied by clean soils and soils not exceeding the MPC by more than 10 times.

The measured BaP contents in the soils of Moscow's EAD were much higher than the $\mathrm{BaP}$ levels recorded in the majority of the other cities (Table 2). However, the comparison of our data with the results of BaP surveys in Moscow, as well as in a number of Russian and Belarusian cities, indicates similarity in the BaP levels. As a rule, the average BaP concentrations in the soil and in the atmospheric fallout make up no more than $10-15 \%$ of the total PAH content (Garban et al., 2002), and maximum concentrations are usually observed in the soils in the industrial and traffic zones.

\subsection{Critical loads of BaP}

In order to determine the critical loads of $\mathrm{BaP}$ on urban soils in the various land-use zones of the EAD, the topsoil reserves of $\mathrm{BaP}$ were calculated. In the calculation, we considered 
Table 2. BaP content in the topsoils in some cities of the world.

\begin{tabular}{|c|c|c|c|c|c|c|}
\hline \multirow[t]{2}{*}{ City } & \multirow{2}{*}{$\begin{array}{r}\text { Number of } \\
\text { samples }\end{array}$} & \multirow{2}{*}{$\begin{array}{l}\text { Method of } \\
\text { analysis }^{\mathrm{a}}\end{array}$} & \multicolumn{3}{|c|}{$\mathrm{BaP}$ concentration, $\mathrm{ng} \mathrm{g}^{-1}$} & \multirow[t]{2}{*}{ Source } \\
\hline & & & mean & $\min$ & $\max$ & \\
\hline Moscow, EAD (Russia) & 50 & 1 & 409 & 0 & 3611 & Authors' data \\
\hline Moscow (Russia) & 40 & 3 & 115 & 2.1 & 840 & Agapkina et al. (2007) \\
\hline St. Petersburg, Vasilyevsky Island (Russia) & 27 & 3 & 237 & 21 & 1004 & Lodygin et al. (2008) \\
\hline Minsk (Belarus) & 22 & 3 & 45 & 10 & 3100 & Kukharchyuk et al. (2013) \\
\hline Chicago (USA) & 57 & 2 & 2307 & 39 & 17000 & Kay et al. (2008) \\
\hline Glasgow (Scotland) & 20 & 3 & 971 & 132 & 3627 & Morillo et al. (2007) \\
\hline Torino (Italy) & 20 & 3 & 229 & 14 & 3170 & Morillo et al. (2007) \\
\hline Ljubljana (Slovenia) & 21 & 3 & 77 & 18 & 186 & Morillo et al. (2007) \\
\hline Bratislava (Slovakia) & 61 & 3 & 195 & 3 & 1200 & Hiller et al. (2015) \\
\hline Miami, residential areas (USA) & 21 & 2 & 185 & $\mathrm{NA}^{\mathrm{b}}$ & NA & Banger et al. (2010) \\
\hline Tallinn (Estonia) & 39 & 1 & 93 & 4 & 542 & Nikiforova et al. (1993) \\
\hline Tallinn (Estonia) & 41 & 3 & 156 & NA & NA & Trapido (1999) \\
\hline Shanghai (China) & 55 & 2 & 119 & 23 & 824 & Jiang et al. (2009) \\
\hline Seville (Spain) & 41 & 3 & 67 & 8 & 378 & Morillo et al. (2008) \\
\hline Beijing and its suburbs (China) & 47 & 2 & 55 & 5 & 270 & Ma et al. (2005) \\
\hline Chiang Mai (Thailand) & 30 & 3 & 22 & 7 & 54 & Amagai et al. (1999) \\
\hline Hong Kong (China) & 138 & 2 & 28 & 0 & 1550 & Chung et al. (2007) \\
\hline Trondheim (Norway) & 75 & NA & 20 & 10 & 2700 & Ottesen et al. (2008) \\
\hline Bergen (Norway) & 435 & NA & 180 & 5 & 9900 & Ottesen et al. (2008) \\
\hline
\end{tabular}

a Methods of analysis were the following: 1, low-temperature spectrofluorimetry; 2, gas chromatography-mass spectrometry; and 3, liquid chromatography and spectrofluorimetry.

b Not available (NA)

the uppermost soil layer with a thickness of $10 \mathrm{~cm}$, an area of $1 \mathrm{~m}^{2}$ and the $\mathrm{BaP}$ concentrations $\left(C, \mathrm{mg} \mathrm{t}^{-1}\right)$ measured in 2010. The topsoil reserves of $\mathrm{BaP}$ are calculated by $B=$ $S \cdot h \cdot \rho \cdot C$, where $B$ is the $\mathrm{BaP}$ reserve in the surface layer of soil in $\mathrm{mg}, S$ is the model area $\left(1 \mathrm{~m}^{2}\right), h$ is the thickness of the soil horizon $(0.1 \mathrm{~m})$ and $\rho$ is its density in $\mathrm{t} \mathrm{m}^{-3}$. The density of urban soils varies from 1.12 to $1.93 \mathrm{~g} \mathrm{~cm}^{-3}$ (Charzyński et al., 2013). Density is one of the diagnostic characteristics of the technogenic horizon of urban soils: it cannot be less that $1.2 \mathrm{~g} \mathrm{~cm}^{-3}$ (Prokof'eva et al., 2014). Therefore, we took the soil density to be $1.2 \mathrm{~g} \mathrm{~cm}^{-3}$ in recreational and agricultural zones and $1.4 \mathrm{~g} \mathrm{~cm}^{-3}$ in all the other zones that are subjected to significant anthropogenic impact. The topsoil reserves $(B)$ in different land-use zones decrease in the following sequence: industrial $(219 \mathrm{mg})$, traffic $(79.2 \mathrm{mg})$, mid-rise residential $(39.6 \mathrm{mg})$, recreational $(19.7 \mathrm{mg})$, low-rise residential $(11.8 \mathrm{mg})$, high-rise residential $(4.84 \mathrm{mg})$ and agricultural $(0.564 \mathrm{mg})$.

The MPC of $20 \mathrm{ng} \mathrm{g}^{-1}$ was used to define the critical level of $\mathrm{BaP}$ in urban soils, below which significant harmful effects on the soil biota do not occur. Critical BaP reserves in the soil surface horizons ( $B_{\mathrm{MPC}}, \mathrm{mg}$ ) correspond to the MPC of $\mathrm{BaP}$ in topsoils. They are $2.4 \mathrm{mg}$ in the agricultural and recreational zones and $2.8 \mathrm{mg}$ in the others.

Because the BaP concentrations exceeded the MPC in the majority of the EAD land-use zones, we considered a load critical if after a specific time interval $(5,10$ or 25 years, etc.) and given the rate of the pollutant's degradation the $\mathrm{BaP}$ content would decrease to the permissible level.

The long-term dynamics of $\mathrm{BaP}$ reserves in the surface soil horizon $(B, \mathrm{mg})$ can be described as follows:

$\frac{\mathrm{d} B}{\mathrm{~d} t}=-\beta \cdot B+v$,

where $\beta$ is the rate of $\mathrm{BaP}$ degradation (year ${ }^{-1}$ ) and $v$ is the intensity of its atmospheric fallout (mg) per $1 \mathrm{~m}^{2}$ per year. This equation assumes that the process of $\mathrm{BaP}$ degradation in soil follows a first-order kinetic model and that $\mathrm{BaP}$ input is constant. $\mathrm{BaP}$ vertical and lateral off-site translocation was ignored because practically all $\mathrm{BaP}$ is absorbed by soil particles (Gennadiev and Pikovskii, 1996; Kosheleva and Nikiforova, 2011).

Equation (1) can be solved by dividing the variables with $-\frac{1}{\beta} \ln (v-\beta \cdot B)=t+\alpha_{0}$,

where $\alpha_{0}$ is a random constant. Transforming this equation gives

$v-\beta \cdot B=e^{-\beta \cdot \alpha_{0}} e^{-\beta t}=\alpha_{1} e^{-\beta t}$.

When $t=0, v-\beta \cdot B=e^{-\beta \cdot \alpha_{0}}=\alpha_{1}$ and $B=B_{0}$, Eq. (2) takes the form $v-\beta \cdot B_{0}=\alpha_{1}$. Taking into account the initial condition, we get the solution of Eq. (1):

$$
B=\frac{v}{\beta}-\left(\frac{v}{\beta}-B_{0}\right) e^{-\beta t} \text {. }
$$


With an annual degradation intensity of $\beta$ and a $\mathrm{BaP}$ fallout rate equal to the critical load $v=D_{\mathrm{MPC}}$, the critical reserve of $\mathrm{BaP}\left(B_{\mathrm{MPC}}\right)$ in the surface layer of soil is $B_{\mathrm{MPC}}=\frac{D_{\mathrm{MPC}}}{\beta}-$ $\left(\frac{D_{\mathrm{MPC}}}{\beta}-B_{0}\right) e^{-\beta t}$ or $B_{\mathrm{MPC}}=\frac{D_{\mathrm{MPC}}}{\beta}\left(1-e^{-\beta t}\right)+B_{0} e^{-\beta t}$.

Then, the BaP critical load is determined by the formula

$D_{\mathrm{MPC}}=\beta\left(B_{\mathrm{MPC}}-B_{0} \cdot e^{-\beta t}\right) /\left(1-e^{-\beta t}\right)$.

The intensity of the relative BaP degradation is given in fractions of 1 . For example, a degradation intensity of $1 \%$ means $\beta=0.01$ and $5 \%$ means $\beta=0.05$, etc.; $t$ is the model time of exposure in years. $\mathrm{BaP}$ can be preserved in soils for many years and decades or for even longer time periods up to hundreds and thousands of years (Shilina et al., 1980; Wild et al., 1991; Gennadiev et al., 2004).

According to the $\beta$ estimates reported in Wild and Jones (1995), the annual degradation intensity in soils is $10 \%$ for PAHs and $6 \%$ for BaP. In order to take into account the variability of the $\mathrm{BaP}$ content in the soils related to different soil conditions, its critical loads were calculated using several values of degradation rates ranging from 1 to $10 \%$ (Fig. 2).

The analysis of Fig. 2 demonstrates that the critical loads ( $D_{\mathrm{MPC}}$ ) vary greatly depending on the $\mathrm{BaP}$ degradation rates and the exposure time in all studied zones, except for the agricultural zone. If the $\mathrm{BaP}$ decomposition is assumed to be slow (1-3\% yearly), the soil pollution in most of the landuse zones will decrease to the permissible level only under insignificant $\mathrm{BaP}$ addition and during long exposure times (over 100 years). If the exposure time is shorter (even in the case of nil atmospheric addition of the pollutant), the BaP reserves in the soil cannot drop below the critical levels, which are $2.4-2.8 \mathrm{mg} \mathrm{m}^{-2}$, due to its low degradation rate. In the agricultural zone, the calculated critical loads of $\mathrm{BaP}$ are tens to hundreds of times higher than the measured pollutant fallout rates because of initially low BaP levels in the soil.

As the $\mathrm{BaP}$ degradation rate increases, so does the value of the critical loads $\left(D_{\mathrm{PMC}}\right)$. However, even at a very high degradation intensity (10\% per year), the non-zero critical loads appear in the high-rise residential areas when the exposure period is longer than 10 years. They appear in the lowrise residential areas with an exposure period over 25 years and in the traffic, industrial and mid-rise residential zones with an exposure time over 50 years, which can be explained by the high initial levels of $\mathrm{BaP}$ in these zones.

The critical $\mathrm{BaP}$ load values calculated using this model demonstrate that at a certain degradation intensity the $\mathrm{BaP}$ concentrations in the EAD soils can decrease to the level of MPC, although this will take a relatively long time. Based on the above formulas, the time necessary for BaP content in the soil to reach the MPC can be calculated as follows:

$T=\ln \left[\left(B_{0}-D / \beta\right) /\left(B_{\mathrm{MPC}}-D / \beta\right)\right] / \beta$,

where $D$ is the BaP load measured in 2010 in $\mathrm{mg} \mathrm{m}^{-2}$ per day. The results of these calculations are shown in Table 3.
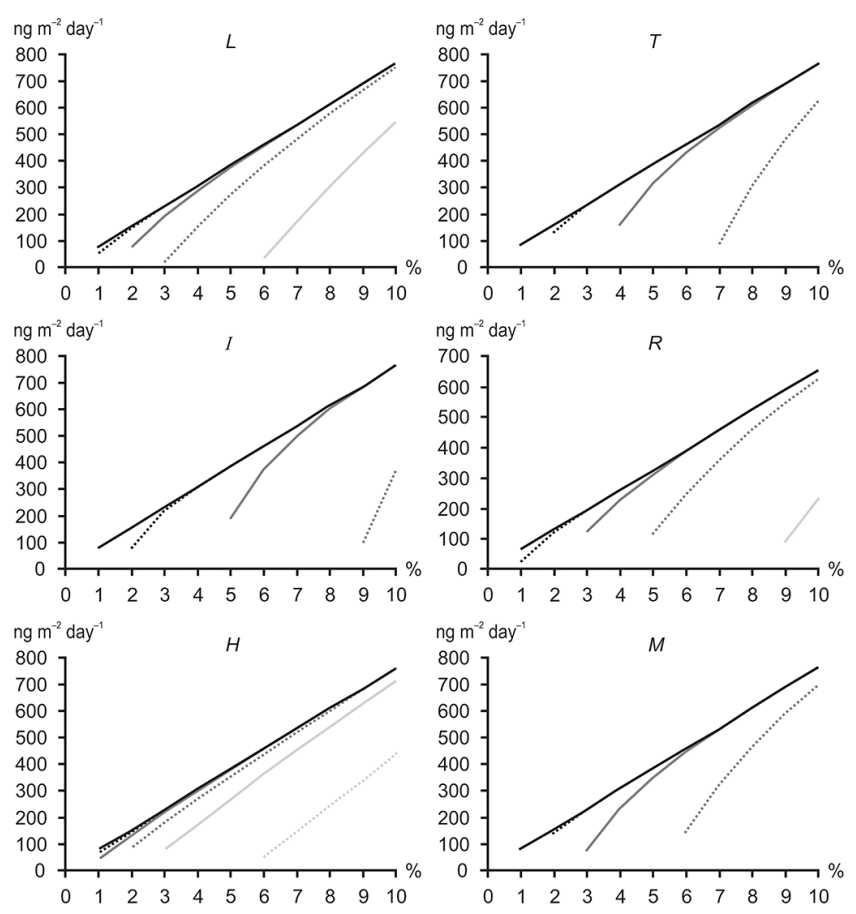

ng $\mathrm{m}^{-2}$ day $^{-1}$

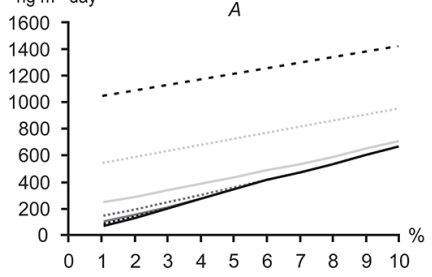

Time of exposure, years

-. 5

10

- 25

…… 50

- 100

$\begin{array}{ll}\cdots & 250 \\ - & 1000\end{array}$

Figure 2. The critical loads of $\mathrm{BaP}\left(\mathrm{ng} \mathrm{m}^{-2} \mathrm{day}^{-1}\right)$ plotted against the degradation intensities (\%) and exposure time (years) for the different land-use zones in the Eastern Administrative District of Moscow. The land-use zone abbreviations are explained in Table 1.

At existing levels of $\mathrm{BaP}$ deposition with insignificant degradation intensity (1-2\%), the $\mathrm{BaP}$ concentrations will reach the MPC in high-rise residential areas in 28-59 years. The BaP concentrations will lower to the MPC in the recreational zone in 106-214 years based on our calculations. It is worth noting that the MPC will never be reached in the other zones because the input of $\mathrm{BaP}$ into the soils exceeds its losses through decomposition.

As the degradation intensity grows, the time period necessary for a decrease in $\mathrm{BaP}$ contents to the permissible level becomes shorter. At $\mathrm{BaP}$ degradation rates of $3-5 \%$ in traffic, industrial and low-rise residential zones, soil $\mathrm{BaP}$ content may gradually decrease to the MPC after a few decades or centuries. The drop in the $\mathrm{BaP}$ content in the soils of the midrise residential quarters can only occur if the rate of degradation is $6 \%$ or more. In the agricultural zone, the $\mathrm{BaP}$ concentrations cannot exceed the permissible level even under low-intensity degradation because of the insignificant addition of $\mathrm{BaP}$ from the atmosphere. 
Table 3. The number of years required to lower the BaP content in the soils of the EAD to the MPC $\left(20 \mathrm{ng} \mathrm{g}^{-1}\right)$ at the existing fallout levels.

\begin{tabular}{lrrrrrrrrrrr}
\hline Land-use zones $^{\mathrm{a}}$ & \multicolumn{8}{c}{ BaP degradation intensity per yearb $^{\mathrm{b}}$} \\
\cline { 2 - 11 } & $1 \%$ & $2 \%$ & $3 \%$ & $4 \%$ & $5 \%$ & $6 \%$ & $7 \%$ & $8 \%$ & $9 \%$ & $10 \%$ \\
\hline $\mathrm{T}$ & $-\mathrm{c}$ & - & 152 & 102 & 78 & 63 & 53 & 46 & 40 & 36 \\
$\mathrm{I}$ & - & - & 202 & 133 & 101 & 81 & 68 & 59 & 52 & 46 \\
$\mathrm{~L}$ & - & - & 97 & 56 & 40 & 31 & 25 & 22 & 19 & 17 \\
$\mathrm{M}$ & - & - & - & - & - & 90 & 60 & 48 & 40 & 34 \\
$\mathrm{H}$ & 59 & 28 & 19 & 14 & 11 & 9 & 8 & 7 & 6 & 6 \\
$\mathrm{~A}$ & - & - & - & - & - & - & - & - & - & - \\
$\mathrm{R}$ & 214 & 106 & 70 & 53 & 42 & 35 & 30 & 26 & 23 & 21 \\
\hline a Land-use zone abbreviations are explained in Table 1. & & & & & & \\
b & The BaP degradation intensity is shown as a percentage of its initial concentration in 2010. \\
c “-” means that at the accepted BaP degradation intensity, the drop in its concentration below the MPC is impossible.
\end{tabular}

Thus, at the existing emission rates of BaP into the atmosphere and its subsequent accumulation in the soil, its content in the soils in all of the land-use areas (except the agricultural zone) may come to the permissible level after decades or hundreds of years. In this situation, to achieve and to maintain environmentally acceptable BaP levels in urban soils, it is necessary to remove the contaminated soil surface layer and replace it with unpolluted soil material as well as to reduce $\mathrm{BaP}$ emissions.

\section{Conclusions}

The intensity of the BaP fallout from the atmosphere onto urban soils with the solid fraction of snow in the EAD territory of Moscow ranged from 0.3 to $1150 \mathrm{ng} \mathrm{m}^{-2}$ per day. The average BaP content in the snow dust was $1942 \mathrm{ng} \mathrm{g}^{-1}$, which is 11.5 times higher than its level in the reference (background) sites. The BaP contents in the snow cover varied dramatically across the land-use zones: from $5732 \mathrm{ng} \mathrm{g}^{-1}$ in the industrial zone and $3605 \mathrm{ng} \mathrm{g}^{-1}$ in the traffic zone to $154 \mathrm{ng} \mathrm{g}^{-1}$ in the recreational zone.

The average $\mathrm{BaP}$ content in the soil surface layers of Moscow's EAD in 2010 was $409 \mathrm{ng} \mathrm{g}^{-1}$, which is 83 times higher than the levels measured in the unpolluted background soils. The district's land-use zones can be arranged by BaP soil enrichment in the following order: industrial, traffic, mid-rise residential, recreational, low-rise residential, highrise residential and agricultural. The $\mathrm{BaP}$ pollution on average exceeded 20 times the norm (MPC). The highest ecological risk posed by the BaP soil pollution was observed in the industrial zone and in the areas situated along large highways (PIs of 78 and 28 respectively), and the lowest risk was observed in the high-rise residential areas $(\mathrm{PI}=1.7)$ and in the agricultural zone $(\mathrm{PI}=0.2)$.

The calculations of the BaP critical loads on the soils in the EAD showed that, at degradation intensities ranging from 1 to $10 \%$ per year, the BaP concentrations may decrease to the permissible level only after a relatively long period of time up to many decades or centuries. Because the urban soils have limited self-purification abilities, a combination of remediation measures must be taken to reduce the ecological risk posed by BaP soil pollution.

The first experience of the application of the critical loads approach for BaP demonstrated its feasibility for contamination control in the urban environment. It also showed the need for further research on BaP entry and loss rates from urban soils, especially in relation to the conditions and rates of $\mathrm{BaP}$ decomposition. A reliable assessment of the pollutant's input and output is the basis for a sound prediction of the long-term dynamics of contamination with highly toxic organic compounds, such as $\mathrm{BaP}$, in the urban environment.

\section{Data availability}

The data used are available in the Supplement.

\section{The Supplement related to this article is available online at doi:10.5194/acp-17-2217-2017-supplement.}

Author contributions. All authors cooperated in designing the experiments. E. Nikiforova, N. Kosheleva and D. Vlasov carried out the fieldwork. D. Vlasov and N. Koshleleva calculated the critical loads of BaP. All authors calculated the pollution levels of $\mathrm{BaP}$ in urban soils and snow cover, and all authors contributed to preparing the paper.

Competing interests. The authors declare that they have no conflict of interest.

Acknowledgements. This study was conducted with financial support from the Russian Science Foundation (project no. 14-2700083). The authors would like to thank the staff of the Department 
of Landscape Geochemistry and Soil Geography at the Faculty of Geography, Lomonosov Moscow State University: N. I. Khlynina for her analytical work as well as M. Y. Lychagin, I. N. Semenkov, T. S. Koshovsky and G. L. Shinkareva for their participation in the fieldwork. We are grateful to E. N. Aseyeva, who helped us to prepare the paper for publication. This work contributes to the Pan-Eurasian Experiment (PEEX) research agenda.

Edited by: V.-M. Kerminen

Reviewed by: A Khaustov and one anonymous referee

\section{References}

Agapkina, G. I., Chikov, P. A., Shelepchikov, A. A., Brodskii, E. S., Feshin, D. B., Bukhan'ko, N. G., and Balashova, S. P.: Polycyclic aromatic hydrocarbons in soils of Moscow, Moscow Univ. Soil Sci. Bull., 62, 149-158, doi:10.3103/S0147687407030076, 2007.

Alekseeva, T. A. and Teplitskaya, T. A.: Methods of Spectrofluorimetric Analysis of Aromatic Hydrocarbons in Natural and Techogenic Environments, Gidrometeoizdat, Leningrad, USSR, 215 pp., 1981 (in Russian).

Amagai, T., Takahashi, Y., and Matsushita, H.: A survey on polycyclic aromatic hydrocarbon concentrations in soil in ChiangMai, Thailand, Environ. Int., 25, 563-572, doi:10.1016/S01604120(99)00026-4, 1999.

Banger, K., Toor, G. S., Chirenje, T., and Ma, L.: Polycyclic Aromatic Hydrocarbons in Urban Soils of Different Land Uses in Miami, Florida, Soil Sediment Contam., 19, 231-243, doi:10.1080/15320380903548516, 2010.

Baskhin, V., Kurbatova, A. S., and Savin, D. S.: A Methodical Basis for the Evaluation of Critical Loads of Pollutants on Urban Ecosystems, NIiPIEG, Moscow, Russia, 64 pp., 2004 (in Russian).

Birgül, A., Tasdemir, Y., and Cindoruk, S. S.: Atmospheric wet and dry deposition of polycyclic aromatic hydrocarbons (PAHs) determined using a modified sampler, Atmos. Res., 101, 341-353, doi:10.1016/j.atmosres.2011.03.012, 2011.

Birke, M., Rauch, U., and Stummeyer, J.: Urban Geochemistry of Berlin, Germany, in: Mapping the Chemical Environment of Urban Areas, edited by: Johnson, C. C., Demetriades, A., Locutura, J., and Ottesen, R. T., John Wiley \& Sons, Ltd, Chichester, UK, 245-268, 2011.

Charzyński, P., Hulisz, P., and Bednarek, R. M. (Eds.): Technogenic soils of Poland, Polish Society of Soil Science, Torun, Poland, 357 pp., 2013.

Chernyansky, S. S., Volosatova, Y., and Krasnopeeva, A. A.: Formation of the anomalies of polyaromatic hydrocarbons in soil cover, Vestnik Moskovskogo Unviersiteta, Ser. Geografiya, 3137, 2007 (in Russian).

Chung, M. K., Hu, R., Cheung, K. C., and Wong, M. H.: Pollutants in Hong Kong soils: polycyclic aromatic hydrocarbons, Chemosphere, 67, 464-473, doi:10.1016/j.chemosphere.2006.09.062, 2007.

Doelman P.: Microbiology of soil and sediments, in: Biogeodynamics of Pollutants in Soils and Sediments, edited by: Salomons, W. and Stigliani, W. M., Springer Berlin Heidelberg, Berlin, Heidelberg, Germany, 31-53, 1995.
Esen, F., Siddik Cindoruk, S., and Tasdemir, Y.: Bulk deposition of polycyclic aromatic hydrocarbons (PAHs) in an industrial site of Turkey, Environ. Pollut., 152, 461-467, doi:10.1016/j.envpol.2007.05.031, 2008.

Fernández, P., Vilanova, R. M., Martínez, C., Appleby, P., and Grimalt, J. O.: The Historical Record of Atmospheric Pyrolytic Pollution over Europe Registered in the Sedimentary PAH from Remote Mountain Lakes, Environ. Sci. Technol., 34, 1906-1913, doi:10.1021/es9912271, 2000.

Gabov, D. N., Beznosikov, V. A., Kondratenok, B. M., and Yakovleva, E. V.: Formation of polycyclic aromatic hydrocarbons in northern and middle taiga soils, Eurasian Soil Sci., 41, 11801188, doi:10.1134/S1064229308110069, 2008.

Gaga, E. O., Tuncel, G., and Tuncel, S. G.: Sources and Wet Deposition Fluxes of Polycyclic Aromatic Hydrocarbons (PAHs) in an Urban Site 1000 Meters High in Central Anatolia (Turkey), Environ. Forensics, 10, 286-298, doi:10.1080/15275920903347594, 2009.

Garban, B., Blanchoud, H., Motelay-Massei, A., Chevreuil, M., and Ollivon, D.: Atmospheric bulk deposition of PAHs onto France: trends from urban to remote sites, Atmos. Environ., 36, 53955403, doi:10.1016/S1352-2310(02)00414-4, 2002.

Gennadiev, A. N. and Pikovskii, Y. (Eds.): Geochemistry of Polycyclic Aromatic Hydrocarbons in Rocks and Soils, Moscow University Publishing, Moscow, Russia, 192 pp., 1996 (in Russian).

Gennadiev, A. N., Pikovskii, Y., Chernyanskii, S. S., Alekseeva, T. A., and Kovach, R. G.: Forms of polycyclic aromatic hydrocarbons and factors of their accumulations in soils affected by technogenic pollution (Moscow Oblast), Eurasian Soil Sci., 37, 697-709, 2004.

Gigliotti, C. L., Totten, L. A., Offenberg, J. H., Dachs, J., Reinfelder, J. R., Nelson, E. D., Glenn 4th, T. R., and Eisenreich, S. J.: Atmospheric Concentrations and Deposition of Polycyclic Aromatic Hydrocarbons to the Mid-Atlantic East Coast Region, Environ. Sci. Technol., 39, 5550-5559, doi:10.1021/es050401k, 2005.

GN 2.1.7.20411-06. Rospotrebnadzor's Federal Center for Hygiene and Epidemiology: Maximum Permissible Concentrations (MPC) of Chemical Compounds in Soil: Hygienic Norms, Moscow, Russia, 2006 (in Russian).

Golomb, D., Ryan, D., Underhill, J., Wade, T., and Zembar, S.: Atmospheric deposition of toxics onto Massachusetts Bay - II. Polycyclic aromatic hydrocarbons, Atmos. Environ., 31, 13611368, doi:10.1016/S1352-2310(96)00277-4, 1997.

Haglund, P., Alsberg, T., Bergman, A., and Jansson, B.: Analysis of halogenated polycyclic aromatic hydrocarbons in urban air, snow and automobile exhaust, Chemosphere, 16, 2441-2450, doi:10.1016/0045-6535(87)90303-1, 1987.

Hautala, E.-L., Rekilä, R., Tarhanen, J., and Ruuskanen, J.: Deposition of motor vehicle emissions and winter maintenance along roadside assessed by snow analyses, Environ. Pollut., 87, 45-49, doi:10.1016/S0269-7491(99)80006-2, 1995.

Hiller, E., Lachká, L., Jurkovič, and Vozár, J.: Polycyclic aromatic hydrocarbons in urban soils from kindergartens and playgrounds in Bratislava, the capital city of Slovakia, Environ. Earth Sci., 73, 7147-7156, doi:10.1007/s12665-014-3894-1, 2015.

Jacob, J.: The significance of polycyclic aromatic hydrocarbons as environmental carcinogens. 35 years research on PAH - a retrospective, Polycycl. Aromat. Compd., 28, 242-272, doi:10.1080/10406630802373772, 2008. 
Jiang, Y.-F., Wang, X.-T., Wang, F., Jia, Y., Wu, M.-H., Sheng, G.-Y., and Fu, J.-M.: Levels, composition profiles and sources of polycyclic aromatic hydrocarbons in urban soil of Shanghai, China, Chemosphere, 75, 1112-1118, doi:10.1016/j.chemosphere.2009.01.027, 2009.

Johnsen, A. R. and Karlson, U.: Diffuse PAH contamination of surface soils: environmental occurrence, bioavailability, and microbial degradation, Appl. Microbiol. Biotechnol., 76, 533-543, doi:10.1007/s00253-007-1045-2, 2007.

Kasimov, N. S. (Ed.): Ecogeochemistry of Urban Landscapes, Moscow University Publishing, Moscow, Russia, 336 pp., 1995 (in Russian).

Kasimov, N. S., Bityukova, V. R., Malkhazova, S. M., Kosheleva, N. E., Nikiforova, E. M., Shartova, N. V., Vlasov, D. V., Timonin, S. A., and Krainov, V. N.: Regions and Cities of Russia: the Integrated Assessment of the Environment, Publisher Filimonov M.V., Moscow, Russia, 560 pp., 2014 (in Russian).

Kay, R. T., Arnold, T. L., Cannon, W. F., and Graham, D.: Concentrations of polycyclic aromatic hydrocarbons and inorganic constituents in ambient surface soils, Chicago, Illinois: 2001-2002, Soil Sediment Contam., 17, 221-236, doi:10.1080/15320380802006939, 2008.

Kleeman, M. J., Schauer, J. J., and Cass, G. R.: Size and Composition Distribution of Fine Particulate Matter Emitted from Motor Vehicles, Environ. Sci. Technol., 34, 1132-1142, doi:10.1021/es981276y, 2000.

Kosheleva, N. E. and Nikiforova, E. M.: Multiyear dynamics and factors of accumulation of benzo(a)pyrene in urban soils (on the example of the Eastern Administrative Okrug, Moscow), Moscow Univ. Soil Sci. Bull., 66, 65-74, doi:10.3103/S0147687411020062, 2011.

Kosheleva, N. E., Kasimov, N. S., and Vlasov, D. V.: Factors of the accumulation of heavy metals and metalloids at geochemical barriers in urban soils, Eurasian Soil Sci., 48, 476-492, doi:10.1134/S1064229315050038, 2015.

Kukharchyk, T. I., Khomich, V. S., Kakareka, S. V., Kurman, P. V., and Kozyrenko, M. I.: Contamination of soils in the urbanized areas of Belarus with polycyclic aromatic hydrocarbons, Eurasian Soil Sci., 46, 145-152, doi:10.1134/S1064229313020099, 2013.

Larsen, R. K. and Baker, J. E.: Source apportionment of polycyclic aromatic hydrocarbons in the urban atmosphere: a comparison of three methods, Environ. Sci. Technol., 37, 1873-1881, doi:10.1021/es0206184, 2003.

Lodygin, E. D., Chukov, S. N., Beznosikov, V. A., and Gabov, D. N.: Polycyclic aromatic hydrocarbons in soils of Vasilievsky Island (St. Petersburg), Eurasian Soil Sci., 41, 1321-1326, doi:10.1134/S1064229308120107, 2008.

Ma, L., Chu, S., Cheng, H., Wang, X., Liu, X., and Xu, X.: Polycyclic aromatic hydrocarbons contamination in subsoil from outskirts of Beijing, People's Republic of China, Geoderma, 129, 200-210, doi:10.1016/j.geoderma.2004.11.026, 2005.

Morillo, E., Romero, A. S., Maqueda, C., Madrid, L., AjmoneMarsan, F., Grcman, H., Davidson, C. M., Hursthouse, A. S., and Villaverde, J.: Soil pollution by PAHs in urban soils: a comparison of three European cities, J. Environ. Monit., 9, 1001-1008, doi:10.1039/B705955H, 2007.

Morillo, E., Romero, A. S., Madrid, L., Villaverde, J., and Maqueda, C.: Characterization and Sources of PAHs and Potentially Toxic Metals in Urban Environments of Sevilla (Southern Spain), Wa- ter Air Soil Pollut., 187, 41-51, doi:10.1007/s11270-007-9495-9, 2008.

Nam, J. J., Sweetman, A. J., and Jones, K. C.: Polynuclear aromatic hydrocarbons (PAHs) in global background soils, J. Environ. Monit., 11, 45-48, doi:10.1039/B813841A, 2009.

Nikiforova, E. M. and Alekseeva, T. A.: Polycyclic aromatic hydrocarbons in soils of suburban agricultural landscapes in Eastern Moscow region, Eurasian Soil Sci., 38, 1213-1225, 2005.

Nikiforova, E. M., Kozin, E. S., and Tsird, K.: The Specifics of Polycyclic Aromatic Hydrocarbon Pollution of Urban Soils Based on the Influence of Heating, Eurasian Soil Sci., 25, 91 102, 1993.

Nikiforova, E. M., Kosheleva, N. E., Labutina, I. A., and Khaybrakhmanov, T. S.: Geoinformation Landscape-Geochemical Mapping of Urban Areas (with the Example of Eastern Administrative District of Moscow), J. Civ. Eng. Sci., 3, 142-151, 2014.

Ollivon, D., Blanchoud, H., Motelay-Massei, A., and Garban, B.: Atmospheric deposition of PAHs to an urban site, Paris, France, Atmos. Environ., 36, 2891-2900, doi:10.1016/S13522310(02)00089-4, 2002.

Ottesen, R. T., Alexander, J., Langedal, M., Haugland, T., and Høygaard, E.: Soil pollution in day-care centers and playgrounds in Norway: national action plan for mapping and remediation, Environ. Geochem. Health, 30, 623-637, doi:10.1007/s10653-0089181-x, 2008.

Pergal, M. M., Tešić, Ž, L., and Popović, A. R.: Influence of Anthropogenic and Environmental Conditions on Polycyclic Aromatic Hydrocarbon Pollution Originating from Coal Ash Dumps, Water Air Soil Pollut., 226, 35, doi:10.1007/s11270-015-2319-4, 2015.

Prokof'eva, T. V., Gerasimova, M. I., Bezuglova, O. S., Bakhmatova, K. A., Gol'eva, A. A., Gorbov, S. N., Zharikova, E. A., Matinyan, N. N., Nakvasina, E. N., and Sivtseva, N. E.: Inclusion of soils and soil-like bodies of urban territories into the Russian soil classification system, Eurasian Soil Sci., 47, 959-967, doi:10.1134/S1064229314100093, 2014.

Revich, B. A., Saet, Y. E., Smirnova, R. S., and Sorokina, E. P.: Methodical Recommendations on the Geochemical Evaluation of Pollution of Urban Territories by Chemical Elements, IMGRE, Moscow, Russia, 112 pp., 1982 (in Russian).

Sharma, M. and McBean, E. A.: PAH deposition to snow surface, Environ. Sci. Pollut. Res., 8, 11-18, doi:10.1007/BF02987290, 2001.

Shilina, A. I., Vaneeva, L. V., and Zhuravleva, A. V.: Benzo(a)pyrene Life Span in Soil After Deposition with Soil Dust Particles, in: Transport of Pollutants in Soil and Adjacent Environments, edited by: Bobovnikova, T. I. and Malakhov, S. G., Gidrometeoizdat, Leningrad, USSR, 100-105, 1980 (in Russian).

Trapido, M.: Polycyclic aromatic hydrocarbons in Estonian soil: contamination and profiles, Environ. Pollut., 105, 67-74, doi:10.1016/S0269-7491(98)00207-3, 1999.

UN DESA: World Urbanization Prospects: The 2014 Revision, United Nations, Department of Economic and Social Affairs, Population Division, New York, USA, 493 pp., 2015.

Vasilenko, V. N., Nazarov, I. M., and Fridman, S. D.: Monitoring of Snow Cover Pollution, Gidrometeoizdat, Leningrad, USSR, 181 pp., 1985 (in Russian). 
Vries, W. de, Bakker, D. J., Sverdrup, H. U., Paces, T., and Tipping, E.: Effect-based approaches to assess the risks of heavy metal inputs to soils. Background document for the workshop on critical limits and effect-based approaches for heavy metals and POP's, Bad Harzburg, Germany, 126 pp., 1997.

Wania, F. and MacKay, D.: Tracking the Distribution of Persistent Organic Pollutants, Environ. Sci. Technol., 30, 390A-396, doi:10.1021/es962399q, 1996.

Wild, S. R. and Jones, K. C.: Polynuclear aromatic hydrocarbons in the United Kingdom environment: a preliminary source inventory and budget, Environ. Pollut., 88, 91-108, doi:10.1016/02697491(95)91052-M, 1995.
Wild, S. R., Obbard, J. P., Munn, C. I., Berrow, M. L., and Jones, K. C.: The long-term persistence of polynuclear aromatic hydrocarbons (PAHs) in an agricultural soil amended with metalcontaminated sewage sludges, Sci. Total Environ., 101, 235-253, doi:10.1016/0048-9697(91)90037-F, 1991.

Yu, B., Xie, X., Ma, L. Q., Kan, H., and Zhou, Q.: Source, distribution, and health risk assessment of polycyclic aromatic hydrocarbons in urban street dust from Tianjin, China, Environ. Sci. Pollut. Res., 21, 2817-2825, doi:10.1007/s11356-013-2190-z, 2014. 